\title{
PEMBERDAYAAN EKONOMI MASYARAKAT MISKIN-KOTA MELALUI PENGEMBANGBIAKKAN KAMBING (Studi pada Program Pengabdian Dosen Institut Agama Islam Negeri Metro)
}

\author{
Imam Mustofa \\ Institut Agama Islam Negeri Metro \\ Jl. Ki Hajar Dewantara 15a, Kota Metro, Lampung, 34112, Indonesia \\ E-mail:imammustofa472@yahoo.co.id \\ Dedi Irwansyah \\ Institut Agama Islam Negeri Metro \\ Jl. Ki Hajar Dewantara 15a, Kota Metro, Lampung, 34112, Indonesia \\ E-mail:dedi.irwansyah@metrouniv.ac.id

\begin{tabular}{c|c|c}
\hline Received: & Revised: & Approved: \\
16/08/2017 & $30 / 11 / 2017$ & $04 / 12 / 2017$ \\
\hline
\end{tabular}

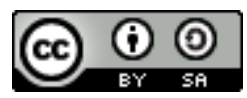 \\ Pemberdayaan Ekonomi Masyarakat Miskin-Kota \\ Melalui pengembangbiakkan kambing (Studi pada Program Pengabdian \\ Dosen Institut Agama Islam Negeri Metro) is licensed under a Creative \\ Commons Attribution-ShareAlike 4.0 International License.
}

\begin{abstract}
Kajian ini merupakan kajian akadmik program pemberdayaan masyarakat yang dilaksanakan oleh Pusat Pengabdian kepada Masyarakat, (PPM) Lembaga Penelitian dan Pengabdian kepada Masyarakat (LPPM) Institut Agama Islam Negeri (IAIN) Metro. Program ini berupa peberdayaan ekonomi melalui komunitas. Lokasi Program pemberdayaan ini difokuskan di Kecamatan Metro Utara. Program pemberdayaan dilaksanakan melalui pengembangbiakkan kambing di keluarahan karangrejo Metro Utara Kota Metro. Subyek pemberdayaan ini adalah jamaah yasinan dan pengajian di Bedeng 23 A, Karangrejo. Tujuan pemberdayaan adalah untuk meningkatkan pengetahuan, keterampilan, taraf hidup subyek dampingan, jamaah yasinan dan pengajian. Lebih dari itu, pemberdayaan ini diharapkan dapat menciptakan komunitas masyarakat yang hidup mandiri. Masyarakat yang mampu mengendalikan kehidupan mereka. Berdasarkan evaluasi dan
\end{abstract}


pengamatan lapangan, kajian ini menyimpulkan bahwa keberhasilan program pemberdayaan melalui pengembangbiakkan kambing tidak hanya ditentukan jumlah modal yang diberikan, akan tetapi oleh spirit dan komitmen subyek pemberdayaan. Selain itu, faktor lain yang mempengaruhi keberhasilan pemberdayaan ini adalah manajemen pengelolaan modal dan aset pemberdayaan. Subyek dampingan yang dipercaya untuk mengembangbiakkan kambing dengan sistem bergulir dan tidak menjadi hak milik, semangat dan komitmen mereka untuk memelihara hewan tersebut lebih tinggi, sehingga pemberdayaan berjalan efektif. Sementara model pemberdayaan yang modalnya berasal dari dana zakat profesi berupa kambing yang diserahkan kepada mustahiq untuk menjadi hak milik dan tidak bergulir, umumnya komitmen dan kesriusan penerima kurang maksimal. Akibatnya, tujuan pemberdayaan tidak tercapai secara maksimal.

Kata kunci: Pemberdayaan ekonomi, subyek pemberdayaan, zakat profesi, dan pengembangbiakkan kambing.

\section{A. Pendahuluan}

Kajian terkait dengan program pemberdayaan marak dilakukan pada satu dekade terakhir. Noor mencatat tiga pilar utama dalam program pemberdayaan masyarakat. Pertama, enabling yaitu penciptaan suasana yang kondusif untuk pengembangan potensi yang dimiliki masyarakat. Kedua, empowering atau memperkuat potensi yang telah dimiliki masyarakat. Ketiga, protecting yaitu terkait dengan upaya maksimal untuk melindungi kepentingan masyarakat. ${ }^{1} \quad$ Ketiga pilar tersebut berorientasi pada peningkatan harkat dan martabat masyarakat kelas bawah agar mereka dapat bangkit dari kebodohan dan kemiskinan.

Kuswandoro meneliti tentang pendekatan good village governance untuk program pemberdayaan masyarakat desa berbasis partisipasi. Kesimpulan peneltian menujuk pada pentingnya sumberdaya desa guna mencapai desa yang berdaya, mandiri, dan partisipatif. Sumberdaya desa, pertama-tama, dapat dikembangkan melalui program peningkatan kapasitas aparat pemerintah desa. Aparat desa yang berkapasitas baik mesti didukung oleh rasa kebersamaan oleh warga (togetherness in collective action) untuk membangun desa. Terakhir, partisipasi masyarakat adalah kunci yang menopang kepemerintahan yang baik (good village governance). ${ }^{2}$

${ }^{1}$ M. Noor, "Pemberdayaan masyarakat," Jurnal Ilmiah CIVIS 1, no. 2 (2011).

2 Kuswandoro, W.E., Strategi pemberdayaan masyarakat desa berbasis partisipasi: pendekatan good village governance untuk implementasi UU Nomor 6 Tahun 2014, 2016, http://www.researchgate.net/publication/311101048. 
Andriyani, Martono, dan Muhammad mengetengahkan bahwa pemberdayaan masyarakat dapat dilakukan melalui pengembangan potensi wisata yang dimiliki oleh sebuah komunitas. Penelitian yang dilakukan di Desa Wisata Penglipuran Bali menunjuk pada pentingnya eksplorasi terhadap pola tata ruang dan bentuk arsitektur bangunan tradisional. Pemberdayaan ditekankan pada keunikan yang dimiliki oleh Desa Wisata Penglipuran Bali yaitu berupa bangunan tradisional dan hutan bambu. Pemberdayaan menjadi berhasil ketika masyarkat lokal terlibat aktif dan ketika pemerintah memberikan pelatihan yang berkesinambungan serta pembinaan teknis terkait dengan kerajinan tangan yang dihasilkan oleh masyarakat.3

Hilman dan Nimasari mengembangkan skema program pemberdayaan komunitas Janda di Kecamatan Balong Kabupaten Ponorogo Jawa Timur. Skema tersebut terdiri dari tiga tahap utama. Pertama, tahap awalan yang dilakukan melalui pemetaan potensi sumber daya alam dan sumber daya manusia. Kedua, tahap proses yang dilakukan melalui pemberian pemahaman, pelatihan, dan pelaksanaan program. Ketiga, tahap luaran, yaitu mengevaluasi dampak dari kegiatan yang telah dilakukan. Terdapat tiga aspek utama dalam evaluasi tersebut yaitu: apakah program pemberdayaan telah meningkatkan pendapatan masyarakat; apakah program pemberdayaan telah mampu menumbuhkan kesetiakawanan sosial; dan apakan program pemberdayaan telah mampu menumbuhkan sikap kemandirin masayarakat. Hasil penelitian menunjukkan bahwa program pemberdayaan komunitas janda menggunakan skema di atas terbukti memberikan dampak positif terhadap kehidupan ekonomi dan psikologi komunitas janda. ${ }^{4}$

Kajian ini merupakan kajian akadmik program pemberdayaan masyarakat yang dilaksanakan oleh Pusat Pengabdian kepada Masyarakat, (PPM) Lembaga Penelitian dan Pengabdian kepada Masyarakat (LPPM) Institut Agama Islam Negeri (IAIN) Metro. Program ini merupakan peberdayaan ekonomi melalui komunitas. Lokasi Program pemberdayaan ini difokuskan di Kecamatan Metro Utara. Di kecamatan Metro Utara pada dasarnya ada beberapa komunitas sosial masyarakat, di anataranya adalah komunitas pengrajin anyaman bambu, komunitas pengrajin jog mobil, komunitas pembuat tahu dan tempe. Ada sutu komunitas yang sudah didampingi dan diberdayakan juga oleh Dosen IAIN Metro, yaitu komunitas pemulung di lingkungan Tempat Pembuangan Akhir (TPA) Kota Metro yangterletak di desa karangrejo.

3 Andriyani, A.A.I, Martono, E, dan Muhamad, “Pemberdayaan masyarakat melalui pengembangan desa wisata dan implikasinya terhadap ketahanan sosial budaya wilayah (studi di Desa Wisata Penglipuran Bali)," Jurnal Ketahanan Nasional 23, no. 1 (2015): 15.

4 Hilman, Y.A dan Nimasari, E.P, "Model program pemberdayaan masyarakat desa berbasis komunitas," ARISTA: Sosial Politik Humaniora 6, no. 1 (2017): 46-67. 
Program pemberdayaan dilaksanakan melalui pengembangbiakkan kambing di keluarahan karangrejo Metro Utara Kota Metro. Subyek pemberdayaan ini adalah jamaah yasinan dan pengajian di Bedeng $23 \mathrm{~A}$, Karangrejo. Tujuan pemberdayaan adalah untuk meningkatkan pengetahuan, keterampilan, taraf hidup subyek dampingan, jamaah yasinan dan pengajian. Lebih dari itu, pemberdayaan ini diharapkan dapat menciptakan komunitas masyarakat yang hidup mandiri. Masyarakat yang mampu mengendalikan kehidupan mereka.

\section{B. Program Pemberdayaan: Urgensi, Langkah Dan Tujuan 1. Urgensi Pemberdayaan}

Konsep 'pemberdayaan' adalah kata kunci. Pemberdayaan adalah sebuah proses dimana individu berjuang untuk mengurangi ketidakberdayaan dan ketergantungan pribadi dengan meningkatkan kendali atas hidup mereka. ${ }^{5}$ Pemberdayaan ini pada dasarnya tidak hanya terbatas pada pemberdayaan masyarakat dalam arti kelompok, akan tetapi juga mencakup pemberdayaan individu. ${ }^{6}$

Miyoux mendefinisikan pemberdayaan sebagai proses perubahan dalam hubungan kekuasaan yang bersifat multidimensional dan saling terkait. ${ }^{7}$ Pemberdayaan pada dasarnya sebagai upaya peningkatan peluang dan pilihan dalam beberapa cara lintas domain sosial, hukum, dan ekonomi. ${ }^{8}$ Artinya, pemberdayaan merupakan kegiatan transformasional yang cukup penting bagi para aktifis dan pekerjas sosial, agar kerja mereka transformasional. ${ }^{9}$ Pemberdayaan juga dianggap sebagai hasil penting dari pengembangan masyarakat.10 Maka bisa dipahami bahwa salah satu unsur terpenting dalam pemberdayaan masyarakat adalah, keaktifan masyarakat sebagai subyek dalam mengatur dan menjalankan agenda. ${ }^{11}$

5 Lord and Hutchison dalam M. Rezaul Islam, NGOs, Social Capital and Community Empowerment in Bangladesh (Singapore: Springer Singapore, 2016), 61, https://doi.org/10.1007/978-981-10-1747-6.

6 Ibid., 61.

${ }^{7}$ Miyoux dalam Anjali Kaur, "Women's Economic Empowerment: Meeting the Needs of Impoverished Women," Workshop Report, (2005), 7.

${ }^{8} \mathrm{H}$ Elizabeth Peters dkk., Women's Economic Empowerment: A Review of Evidence on Enablers and Barriers (Canada: Hewlett Foundation, 2016), 5.

${ }_{9}$ Robert Adams, Social Work and Empowerment, 3rd ed, Practical Social Work (Basingstoke: Palgrave Macmillan, 2003), 3.

${ }_{10}$ Barnes et al. 1997 dalam M. Rezaul Islam, NGOs, Social Capital and Community Empowerment in Bangladesh, 68.

11 David L Adamson, Richard Bromiley, dan Joseph Rowntree Foundation, Community Empowerment in Practice: Lessons from Communities First (York: Joseph Rowntree Foundation, 2008), 11. 
Pemberdayaan masyarakat sebagai bentuk pengabdian merupakan tanggung jawab moral, tanggung jawab intelektual dan sekaligus tanggung jawab sosial bagi kampus melalui para akademisi, terutama dosen. ${ }^{12}$ Selain itu, pemberdayaan merupakan bentuk pengabdian yang menjadi tugas dan kewajiban perguruan tinggi, ${ }^{13}$ karena salah satu dharma dri tiga dharma yang harus dilaksanakan secara serius. ${ }^{14}$

Sementara itu, bagi masyarakat pemberdayaan menjadi penting karena ia menjadi sarana bagi mereka untuk mendapatkan pendampingan dan motivasi dalam melakukanperubahan dan peningkatan pengetahuan, taraf hidup dan kesejahteraan, baik individu maupun kelompok.15 Biasanya dalam sebuah wilayah tertentu ada sumber daya alam yang cukup, namun sumberdaya manusianya tidak kapabel untuk mengolahnya untuk peningkatan kesjahteraan.16 Artinya ada gap antara human resource sebagai aset sosial dengan sumber daya alam yang ada.17 Di sinilah pentingnya pemberdayaan dan pendampingan dari dunia kampus kepada masyarakat untuk menjembatani gap tersebut.

12 Baca Radiah Othman dan Roslan Othman, "Higher Education Institutions And Social Performance: Evidence from Public And Private Universities," International Journal of Business and Society 15, no. 1 (2014); Baca R Seminur Topal, "CSR in Universities Around the World," SRRNet, 2009, 23; dan Baca Alina Mihaela Dima dkk., "A Model Of Academic Social Responsibility," t.t., 21.

13 Subhan Arif, "Peranan Dosen IAIN Raden Intan Lapung dalam Pemberdayaan Melalui Pengabdian Masyarakat di Kec. Sukarame Bandar Lampung," Jurnal Ilmu dakwah Dan Pengembangan Komunitas 9, no. 2 (2014): 250-264.

14 Baca Sukaina A Alzyoud dan Kamal Bani-Hani, "Social Responsibility In Higher Education Institutions: Application Case from the Middle East," European Scientific Journal 11, no. 8 (2015): 123-26; dan Baca juga Chripa Schneller dan Erich Thoni, ed., Knowledge Societies: Universities and Their Social Responsibilities (Singapore: Asia-Europe Foundation, 2011).

15 Baca Anu Kasmel dan Pernille Tanggaard Andersen, "Measurement of Community Empowerment in Three Community Programs in Rapla (Estonia)," International Journal of Environmental Research and Public Health 8, no. 3 (11 Maret 2011): 799-817, https://doi.org/10.3390/ijerph8030799; Dan Baca Juga Peter Dreier, "Community Empowerment Strategies: The Limits and Potential of Community Organizing in Urban Neighborhoods," Cityscape: A Journal of Policy Development and Research 2, no. 2 (1996): 39.

16 Baca Andi Haris, "Memahami Pendekatan Pemberdayaan Masyarakat Melalui Pemanfaatan Media," JUPITER XIII, no. 2 (2014): 51. Lihat Juga Munawar Noor, “Pemberdayaan Masyarakat," Jurnal Ilmiah CIVIS 1, no. 2 (2011): 89.

17 Yunus Winoto, "Pemberdayaan Masyarakat (Community Empowerment) Melalui Penyelenggaraan Taman Bacaan Masyarakat (TBM): Studi kasus mengenai penyelenggaraan taman bacaan masyarakat (TBM) di wilayah Kabupaten Bandung" (Prosiding Seminar Nasional Pendidikan FKIP UNTIRTA, Serang, 2017), 206. 


\section{Langkah Pelaksanaa Pemberdayaan}

Sebuah program pemberdayaan diharapkan bisa berjalan secara efektif, efisien dan tercapainya target tujuan yang telah ditentukan. Ada beberapa langkah yang harus ditempuh dalam sebuah program pemberdayaan. Langkahlangah tersbut adalah sebagai berikut:

\section{a. Membangun kesadaran dan komitmen}

Membangun kesadaran dan komitmen subyek pemberdayaan akan pentingnya peningkatan kualitas diri dan kualitas hidup menjadi dalam program pemberdayaan merupakan hal penting yang harus lakukan pertama kali. Dalam pemberdayaan, diperlukan tindakan berbasis pada kesadaran masyarakat untuk membebaskan diri dari belenggu kekuatan ekonomi dan politik yang menghambat proses demokratisasi ekonomi. Penyuluhan yang berorientasi pada sasaran merupakan pendekatan yang sangat penting sebagai upaya membangun kesadaran masyarakat. ${ }^{18}$

Langkah di atas perlu dilakukan untuk membangkitkan semangat dan komitmen mereka, khususnya semangat untuk meningkatkan pengetahuan, skill dan kapasitas diri mereka. Proses pembangunan kesadarandiri ini bisa dilakukan dengan cara diskusi, sharing dan melakukan Focus Group Discussion sederhana secara rutin. Artinya langkah ini dilakukan bersama dalam kelompok komunitas. ${ }^{19}$

\section{b. Identifikasi masalah dan perencanaan}

Langkah selanjutnya yang ditempuh dalam pelaksanaan pemberdayaan

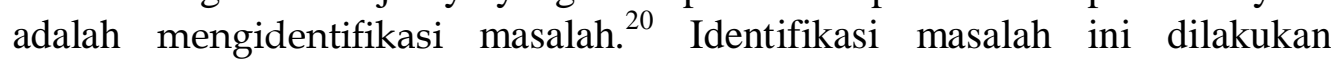
bersama antara pelaksana program dengan subyek pemberdayaan. Identifikasi masalah ini penting dalam rangka menentukan strategi dan teknik yang tepat dalam pelaksanaan program. ${ }^{21}$

18 Ravik Karsidi, "Paradigma Baru Penyuluhan Pembangunan dalam Pemberdayaan Masyarakat," Mediator 2, no. 1 (2001): 122.

19 Sumarti dalam Dahlan Tampubolon, "Strategi Pemberdayaan Masyarakat Pesisir Di Kabupaten Kepulauan Meranti," SOROT 9, no. 1 (20 Oktober 2014): 154, doi:10.31258/sorot.8.2.2358.

20 Ravik Karsidi, "Paradigma Baru Penyuluhan Pembangunan dalam Pemberdayaan Masyarakat," 123.

21 Baca Bambang Sigit Subiyanto, "Strategi Pemberdayaan Masyarakat," 2013, 4; dan Baca juga Flores G Mayaut, "Identifikasi Masalah Dan Upaya Pemberdayaan Nelayan: Telaah Pada Nelayan di RW 01 Kelurahan Kamal Muara, Kecamatan Penjaringan, Jakarta Utara," INSANI, no. 13 (2012): 7. 
Setelah identifikasi masalah dlakansakan, maka pelaksana program bersama dengan subyek pemberdayaan melakukan perencanaan program secara bersama. Perencanaan program sebagai suatu prosedur kerja bersamasama masyarakat dalam upaya untuk merumuskan masalah dan upaya pemecahan yang mungkin dapat dilakukan demi tercapainya tujuan dan sasaran yang ingin dicapai. ${ }^{22}$ Masyarakat akan lebih mempercayai proyek atau program jika dilibatkan dalam proses persiapan dan perencanaannya. ${ }^{23}$ Salah satu tujuan perencanaan program pemberdayaaan masyarakat secara partisipatif adalah menggali masukan, pendapat, usulan dan saran-saran dari masyarakat guna memperkuat dan mendukung program pemberdayaan masyarakat. ${ }^{24}$ Perenacaan ini harus dilakukan secara matang, agar target dan tujuan yang akan dicapai bisa tercapai secara efisien dan maksimal.

\section{c. Memperkuat komunitas}

Bila subyek pemberdayaan adalah komunitas, maka memperkuat posisi dan optimalisasi peran komuntas harus ditempuh dalam pelaksanaan pemberdayaan. ${ }^{25}$ Langkah dalam rangka pengembangan organisasi/kelompok masyarakat yang dikembangkan dan berfungsi dalam mendinamisasi kegiatan produktif masyarakat. selain itu, perlu pengembangan jaringan strategis antarkelompok/organisasi masyarakat yang terbentuk dan berperan dalam pengembangan masyarakat. ${ }^{26}$

Penguatan komunitas ini bisa dilakukan dengan strukturisasi atau bahkan restruktrisasi komunitas, agar Sumberdaya manusia yang ada bisa berperan maksimal sesuai dengan kapasitasnya dan sejalan dengan perencanaan yang sudah disusun sebelumnya. Hal ini tentunya dilaksanakan dengan melibatkan semua komponen dan anggota komunitas.

${ }^{22}$ Burhanudin AY, "Perencanaan Program Pemberdayaan Menuju Perubahan Dalam Masyarakat," Paradigma 5, no. 1 (2008): 47.

${ }^{23}$ Hasim dan Remiswai dalam Dewi Maryam, "Perencanaan Partisipatif Dalam Pemberdayaan Masyarakat (Studi Kasus Pelaksanaan Musyawarah Perencanaan Pembangunan (Musrenbang) di Desa Kebumen Kecamatan Sumberjo," Jurnal Ilmu dakwah Dan Pengembangan Komunitas X, no. 1 (2015): 5.

24 Ibid., 13; Baca juga Martua Hasiholan Bancin, "Peningkatan Partisipasi Masyarakat Dalam Program Nasional Pemberdayaan Masyarakat (Pnpm) Mandiri Perdesaan (Studi Kasus: Bandung Barat)," Jurnal Perencanaan Wilayah dan Kota 22, no. 3 (2011): 180.

25 Baca Trisni Utami, "Pemberdayaan Komunitas Sektor Informal Pedagang Kaki Lima (Pkl), Suatu Alternatif Penanggulangan Kemiskinan" 25, no. 2 (2010): 10.

26 Ravik Karsidi, "Paradigma Baru Penyuluhan Pembangunan dalam Pemberdayaan Masyarakat," 122. 


\section{d. Mengoneksikan resource dengan source}

Pengoneksian antara sumber daya manusi dengan bahan yang tersedia merupakan bagian terpenting dalam sebuah program pemberdayaan. Bagian ini merupakan bagian inti dalam pelaksanaan pemberdayaan. Konektifitas antara source dan resource ini ditindak lanjuti dengan pelaksanaan program yang telah direncanakan. ${ }^{27}$

\section{e. Evaluasi program}

Evaluasi merupakan bagian akhir dan terpenting dalam setiap program, termasuk program pemberdayaan. ${ }^{28}$ Evaluasi pada umumnya, dilakukan untuk mengumpulkan informasi mengenai sesuatu program kegiatan atau proyek. Informasi ini biasanya berguna untuk pengambilan keputusan, seperti penyempurnaan lebih lanjut dari suatu kegiatan, atau penghentian suatu kegiatan proyek, atau penyebarluasan suatu gagasan yang mendasari suatu kegiatan yang sedang diujicobakan. ${ }^{29}$ Evaluasi bertujuan untuk menganalisis keberhasilan program berdasarkan perspektif pemberdayaan masyarakat. Hal tersebut bertujuan untuk mengetahui apakah masyarakat benar-benar menjadi berdaya atau hanya bergantung pada program pemberdayaan. ${ }^{30}$

Evaluasi ini pada dasarnya tidak selalu dilaksanakan di akhir program. Ia bisa dijalankan secara berkala selama program pemberdayaan dijalankan. Evaluasi ini dilakukan untuk mengidentifikasi permasalah yang ditemukan selama pelaksanaan program dan sekaligus mencari soslusi yang tepat secara tepat. Dengan adanya evaluasi berkala ini maka pelaksanaa program akan berjalan semakin baik dan maksimal.

\section{Tujuan Program Pemberdayaan}

Pemberdayaan setidaknya harus mencapai tiga tujuan pokok, peningkatan pengetahuan dan skill subyek pemberdayaan, peningkatan taraf hidup dan kesejahteraan subyek pemberdayaan dan kemandirian hidup subyek pemberdayaan. Pencapaian tiga tujuan inti ini saling terkait sama lain, hanya saja tujuan pertama merupakan tujuan paling urgen diantara ketiganya. Tiga tujuan tersebut juga tersusun secara hirakis piramidal.

27 Baca Steve et, Building Community Capacity Resources for Community Learning $\mathcal{E}$ Development Practice (Scottish Government, 2007), 68-69; dan Baca juga Anonim, Achieving Community Empowerment, t.t., 18.

28 Baca Jaclyn Redekop, "Evaluating Community Development Programs: Who speaks? Who listens? Who cares?" (Tesis, University of Manitoba, 2013).

29 Ratna Sari Dewi, "Evaluasi Program Pemberdayaan Masyarakat Melalui Pendidikan Kewirausahaan Masyarakat (Pkm) Program Nasional Pemberdayaan Masyarakat (Pnpm) Di Desa Balonggandu Kecamatan Jatisari Kabupaten Karawang" 1, no. 2: 159.

30 Ibid., 3. 


\section{a. Peningkatan pengetahuan dan Skill subyek pemberdayaan}

Subyek pemberdayaan dalam sebuah program pemberdayaan tidak selalu pada posisi "gelas kosong". Artinya mereka bukanlah individu atau kelompok yang sama sekali tidak memeliki pengetahuan dan skill sama sekali. Berdasarkan hal ini, maka tujuan yang pertama kali harus tercapai adalah adanya peningkatan kapasitas diri, pengetahuan dan keterampilan subyek pemberdayaan. Meskiipun kegiatan utama program pemberdayaan misalnya pada pemberdayaan dalam bidang ekonomi, namun tujuan utama yang pertama kali harus dicapai bukanlah peningkatan pendapatan, akan tetapi peningkatan pengetahuan dan keterampilan. ${ }^{31}$

Tujuan untuk menjadikan subyek pemberdayaan menjadi individu atau kelompok yang well educated sesuai dengan kapasitas mereka. Bila tujuan ini tercapai, maka subyek pemberdayaan akan bisa menyesuaikan diri dengan kehidupan dan problem yang dihadapi di lain waktu atau di lain tempat.

\section{b. Peningkatan kualitas hidup dan kesejahteraan subyek pemberdayaan}

Program pemberdayaan umumnya tidak jauh dari kegiatan ekonomi yang target dan tujuannya adalah adanya peningkatan kualitas hidup subyek pemberdayaan. $^{32}$ Subyek pemberdayaan dalam sebuah perogram pemberdayaan biasanya ditentukan dengan berbagai pertimbangan kriteria yang intinya mereka perlu dan segera didampingi dan diberdayakan. Pertimbangan umum biasanya kondisi pengetahuan dan ekonomi yang berada di bawah standar rata-rata. Subyek pemberdayaan biasanya adalah masyarakat miskin, khususnya masyarakat masikin dalam kategori "miskin absolut". Pemberdayaan dan pengembangan masyarakat adalah pendekatan dalam program pembangunan yang bertujuan untuk meningkatkan kondisi kehidupan orang-orang di daerah tertentu. Ini juga merupakan strategi untuk menjangkau dan melibatkan desa dan masyarakat dalam proses membangun kehidupan mereka sendiri, yang akibatnya akan berkontribusi pada kemajuan nasional. Ini juga merupakan gerakan yang terkait dengan pemerintah lokal untuk mempromosikan kondisi kehidupan yang lebih baik bagi seluruh masyarakat dengan partisipasi aktif, dan inisiatif yang mungkin dari masyarakat. ${ }^{33}$

31 Anonim, Achieving Community Empowerment, 3.

32 Anu Kasmel dan Pernille Tanggaard Andersen, "Measurement of Community Empowerment in Three Community Programs in Rapla (Estonia)," 800. Baca juga Shannon Mason, Judiann McNulty, dan Judi Aubel, "Participation for Empowerment," 2001, vi.

33 Frances Hedayat Allah Nikkhah, "Participation as a Medium of Empowerment in Community Development," European Journal of Social Sciences 11, 
Program pemberdayaan harus dapat membawa prubahan bagi kehidupan subyek pemberdayaan. Pemberdayaan dalam kegiatan ekonomi diharapkan mampu menjadi sarana peningkatan produktifitas kinerja, karya dan pendapatan mereka. Dengan adanya peningkatan produktifitas kerja dankarya maka akan dapat meningkatkan taraf hidup dan kesejahteraan.

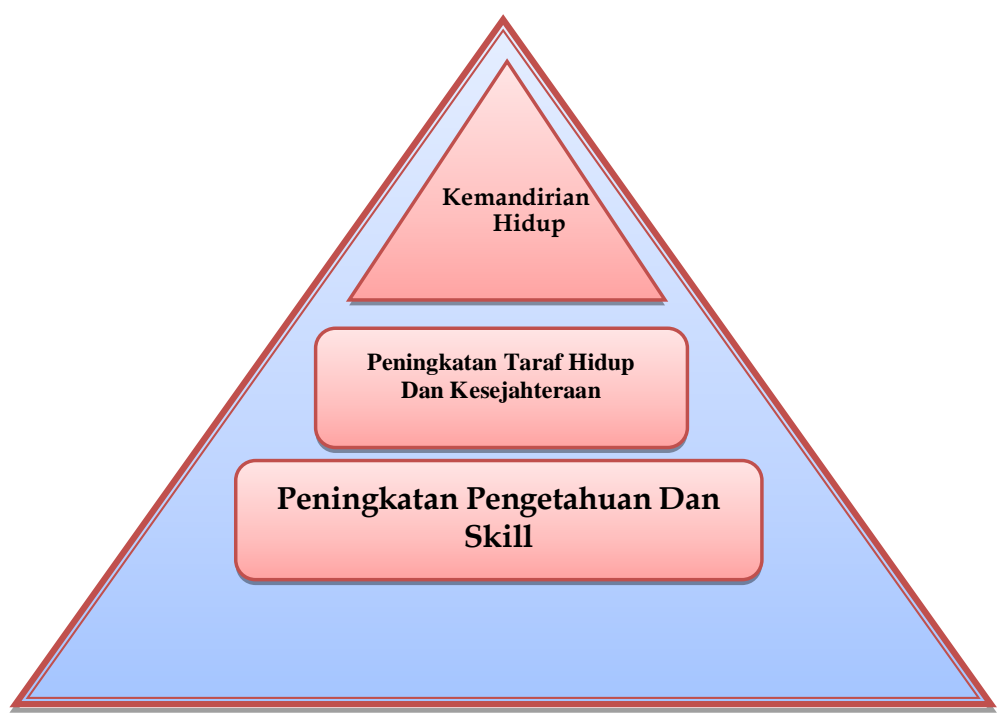

\section{c. Kemandirian hidup subyek pemberdayaan}

Kemandirian hidup subyek pemberdayaan merupakan tujuan akhir dan sekaligus menjadi target yang harus dicapai ${ }^{34}$ Kemandirian hidup ini penting, untuk menghindarkan mereka dari ketergantungan terhapap palaksana program, lingkungan dan ketergantungan terhadap pemberi bantuan, terutama dari pemerintah. Artinya, pemberdayaanharus membuat mereka mandiri dan

no. 1 (2009): 170 Baca juga; Shannon Mason, Judiann McNulty, dan Judi Aubel, "Participation for Empowerment."

34 Takashi Miyazaki, "Community Development as Community Empowerment," Study of Community Education, no. 33 (2015): 8. 
tidak tergantung pada pemberian. ${ }^{35}$ Dengan adanya kemandirian hidup, maka subyek pemberdayaan siap untuk "dilepas" oleh pelaksana program dan diharapkan mereka mampu melanjutkan program atau membuat kreasi dan inovasi program baru sesuai dengan kemampuan dan kebutuhan yang mereka dapatkan selama program pemberdayaan.

\section{Mengapa Subyek pemberdayaan di Kota Metro?}

Pemberdayaan masyarakat di Kota Metro melalui pemberdayaan ekonomi, pengembangbiakan kambing difokuskan di Kota Metro, khususnya Metro Utara dengan berbagai pertimbangan dan alasan. Alasan yang paling fundamnetal adalah:

\section{Adanya Komunitas}

Semua dimensi kehidupan manusia telah dilanda globalisasi yang dicirikan oleh kehidupan yang semakin individualistis, ikatan-ikatan makin longgar, dan tergerusnya modal sosial. Diperlukan langkah strategis untuk menumbuhkembangkan dan menguatkan modal sosial bangsa. ${ }^{36}$ penguatan ini akan efektif bila dilakukan melalui sebuah komunitas. McMillan dan Chavis Menegaskan bahwa komunitas merupakan kumpulan yang terdiri dari para anggotanya yang memiliki rasa saling memiliki, terikat diantara satu dan lainnya dan percaya bahwa kebutuhan para anggota akan terpenuhi selama para anggota berkomitmen untuk terus bersama-sama. ${ }^{37}$

Sebuah komunitas, menurut McMillan harus memenuhi unsur-unsur sebagi berikut, pertama, kenaggotaan (Membership). Dalam konteks komunitas, keanggotaan merupakan ikatan yang menimbulkan perasaan memiliki atau berbagi rasa keterkaitan pribadi dalam kelompok. ${ }^{38}$

Komunitas merupakan kelompok yang digambarkan di mana individu adalah anggotabagian dari komunitas tersebut. Anggota sebuah komunitas harus dapat anggota lainnya, mempunyai rasa memiliki yang kuat, serta

35 Andi Sopandi, "Strategi Pemberdayaan Masyarakat: Studi Kasus Strategi Dan Kebijakan Pemberdayaan Masyarakat Di Kabupaten Bekasi," Jurnal Kybernan 1, no. 1 (2010): 41.X.

36 Rokhani, "Penguatan Modal Sosial Dalam Penanganan Produk Olahan Kopi Pada Komunitas Petani Kopi Di Kabupaten Jember," J-SEP 6, no. 1 (2012): 20.

${ }^{37}$ McMillan, D.W dan Chavis, D.M, "Sense of community: A definition and theory," American Journal of Community Psychology 14, no. 1 (1986): 9.

${ }^{38}$ Ibid. 
menjaga proporsionalitas di saaat kepentingan komunitas bersentuhan dengan kebebasan individu. ${ }^{39}$

Kedua, pengaruh (influence). Pengaruh dalam konteks komunitas adalah konsep dua arah yang mencakup pengaruh anggota atas grup dan timbal balik mempengaruhi kelompok terhadap anggota individualnya. Pada tingkat pribadi, pengaruh adalah "rasa" mampu untuk mengakui nilai dan pendapat anggota lain dan bereaksi terhadapnya. Tanpa elemen pengaruhnya, anggota dalam suatu komunitas akan merasa kurang termotivasi untuk berpartisipasi dalam komunitas, karena seringkali orang tertarik pada komunitas yang menawarkan mereka kesempatan untuk merasa berpengaruh. $^{40}$

Ketiga, pemenuhan kebutuhan (fulfillment of needs). Pemenuhan kebutuhan berarti bahwa perilaku dan kebutuhan yang dianggap oleh masyarakat sebagai konstruktif diperkuat dan dihargai, sementara perilaku yang tidak diinginkan dihukum. ${ }^{41}$ Pemenuhan kebutuhan dalam konteks ini tidak terpaku pada kebutuhan materiil, akan teteapi lebih difokuskan pada kebutuhan immateriil. Pemenuhan kebutuahan dalamkomunitas antara lain meliputu rasa saling percaya, saling menghargai, rasa persatuan, kebersamaan dan rasa nyaman berada dalam kelompok.

Keempat, koneksi emosional bersama (shared emotional connection). Hubungan emosional bersama untuk menjadi komunitas sejati, yaitu sebagai anggota komunitas yang kuat. Kelompok komunitas semacam ini adalah mereka yang menawarkan cara-cara positif kepada anggota untuk berinteraksi, peristiwa penting untuk dibagikan dan cara untuk menyelesaikannya secara positif, peluang untuk menghormati anggota, peluang untuk berinvestasi dalam komunitas, dan peluang untuk mengalami ikatan spiritual antar anggota. $^{42}$

Selain empata unsur diat as, ada stau unsur lagi yang juga pendting yang ada dalam sebuah komunitas, yaitu adanya kepentingan yang sama. ${ }^{43}$ Kesamaan kepentingan ini pada dasarnya tidak sama persis, akan tetepi adanya 2-3.

${ }^{39}$ Caroline Heller, "Community Empowerment And Capacity Building," 2014,

${ }^{40}$ McMillan, D.W dan Chavis, D.M, "Sense of community: A definition and theory," 11 .

${ }^{41}$ Ibid., 12.

42 Ibid., 13-14.

${ }^{43}$ Dana Rotman dan PhiliP Fei Wu, Sense of Community in Virtual Environments (New York: ME Sharpe, 2014), 42. 
kesamaan-kesamaan sifat. Lebih dari itu, kepentingan ini tidak hanya berupa kepentingan materi, akan tetapi lebih dari itu, yaitu kepentingan immateri.

Berdasarkan kriteria di atas, maka jamaah yang menjadi subyek pemberdayaan pemberdayaan ini bisa dikategorikan sebagai komunitas. Komuitas yang terdiri dari para angota jamaah yasinan dan pengajian di Bedeng 23 A, kelurahan Karangrejo.

Pada dasarnya, di wilayah keluarah Karangrejo terdapat banyak jamaah Yasinan baik yang beranggota Bapak-bapak maupu yang beranggota ibu-ibu. Satu jamaah Yasinan biasanya terdiri dari 40-60 orang jamaah. jamaah yasinan dan pengajian ini melaksanakan kegiatan rutin mingguaan berupa membaca surat Yasin dan dilanjutkan dengan pengajian atau ceramah agama. Yasinan dan Pengajian dilaksanakan ada yang malam hari, khusus untuk jamaah yasinan bapak-bapak, dan untuk jamaah Yasinan Ibu-ibu dilaksanakan di pada siang hari. Tempat kegiatan biasanya berpindah-pindah dari satu rumah jamaah ke rumah lainnya.

Pemberdayaan dan pendampingan dalam kajian ini fokus pada jamaah Yasinan dan pengajian di bedeng 23 A, kelurahan Karangrejo Metro utara, Kota Metro. Jamaah Yasinan dan Pengajian dipilih sebagai subyek pemberdayaan dengan beberapa alasan, pertama, umumnya pengetahuan agama masyarakat bedeng 23 A Kelurahan Karangrejo maih minim, namun semangat mereka untuk mengaji dan berkumpul bersama jamaah lainnya cukup tinggi. Pengetahuan mereka terhadapilmu agama pada tingkat dasar, seperti membaca al-Quran, fikih, akidah dan ketentuanmu'amalah dalam fikih dibilang masih rendah. Di sisi lain, semangat mereka untuk berkumpul dan belajar cukup kuat, hal ini terlihat dari banyaknya jumlah jamaah pengajian dan jamaah yasinan, baikyang dilaksanakan dua kali seminggu di masjid, maupun yang dilaksanakan mingguan di rumah-rumah.

Kedua, jamaah yasinan dan pengajian di keluarahan Karangrejo tersebut umumnya adalah petani. Dengan pemberdayaan ekonomi berupa budidaya kambing yang mengandalkan pakan ternak dari rumput liar, maka ubyek dampingan yang paling tepat adalah petani. Setiap hari petani pergike sawah atau ke ladang. Di situ merek menemukan sumber pakan ternak kambing mereka.

Ketiga, adanya persatuan yang kuat di antara para jamaah Yasinan dan Pengajian di Karangrejo tersebut. Budaya gotong royong, rewang, ambengan, genduren dan budaya-budaya lain yang menjadi ajang berkumpulnya para jamaah tersebut masih sangat intens dilaksanakan. Momen-momen perkupulan 
tersebut menjadi sarana untuk saling bertukar pikiran berbagi, melestarikan dan mempererat persaudaan dan persatuan serta kekompakan jamaah.

\section{Ketersediaan modal sosial}

Istilah 'modal sosial' telah menjadi subyek minat dan perdebatan besar dalam literatur pembangunan. Ini telah diuraikan begitu luas sehingga sangat sulit untuk menjelaskan konteks teoretisnya secara singkat. ${ }^{44}$ Modal sosial bukanlah modal dalam arti biasa seperti harta kekayaan atau uang, tetapi lebih mengandung arti kiasan, namun merupakan aset atau modal nyata yang penting dalam hidup bermasyarakat. Menurut Hanifan, dalam modal sosial termasuk kemauan baik, rasa bersahabat, saling simpati, serta hubungan sosial dan kerjasama yang erat antara individu dan keluarga yang membentuk suatu kelompok sosial. ${ }^{45}$ Secara umum, modal sosial merupakan sumberdaya bersama yang digunakan untuk kepentingan bersama. ${ }^{46}$

Persatuan dan kuatnya busaya gotong-royong saling membantu yang hidup di masyarakat keluarahan Karangrejo merupakan modal fundamental untuk pemberdayaan mereka, khususnya yang menjadi subyek pemberdayaan. Budaya dan kearifan lokal yang mereka pegangi dan laksanakan menjadi kontribusi besar bagi pemberdayaan masyarakat subyek pemberdayaan. Karena pada dasarnya modal sosial merupakan sumbangan lokal penting yang mengarah ke pembangunan lokal. ${ }^{47}$ Masyarakat karangrejo sudah membuka pintu kerjasama untuk membagun masyarakat, baik terkait pengetahuan agama, maupun pemberdayaan ekonomi masyarakat.

Persatuan di antara jamaah dan antara jamaah yasinan dan jamaah pengajian di kecamatan Metro Utara merupakan jaringan sosial yang dapat memperkuat subyek pemberdayaan. Hal ini akan memnjadi modal bagi pemberdayaan asyarakat. Karena jaringan sosial merupakan bagian yangsangat pentingd dalam komponen modal sosial. Putman menegaskan bahwa jaringan sosial bagian penting dari modal sosial yang menjadi "fitur organisasi sosial"

${ }_{44}$ M. Rezaul Islam, NGOs, Social Capital and Community Empowerment in Bangladesh, 2; Baca juga Alan Kay, "Social Capital, the Social Economy and Community Development," Community Development Journal 41, no. 2 (1 April 2006): 160, doi:10.1093/cdj/bsi045.

${ }^{45}$ Hanifah dalam Rusydi Syahra, "Modal Sosial: Konsep dan Aplikasi," Jurnal Masyarakat dan Budaya 5, no. 1 (2003): 2.

46 Anyualatha Haridison, "Modal Sosial dalam Pembangunan," JISPAR, FISIP Universitas Palangka Raya 4 (2013): 33.

47 Fox dalam M. Rezaul Islam, NGOs, Social Capital and Community Empowerment in Bangladesh, 68. 
yang di dalamnya memuat norma, dan kepercayaan sosial yang memfasilitasi koordinasi dan kerja sama untuk saling menguntungkan. ${ }^{48}$

Tujuan luas modal sosial adalah untuk mengamankan komunitas berbasis aset, yang merupakan pendekatan yang relatif baru untuk menjaga dan mengembangkan partisipasi masyarakat dalam pemberdayaan dan pembangunan. Proses ini membantu menggabungkan masalah lingkungan, ekonomi, sosial, demografi, teknologi, politik dan lainnya dengan memberdayakan masyarakat. ${ }^{49}$ Inilah yang menjadi salah satu alasan penting kami malaksanakan pemberdayaan di tengah masyarakt yang memiliki karakteristik sebagai modal sosial.

\section{Adanya masyarakat miskin kota}

Kecamatan Metro Utara, khususnya kelurahan Karangrejo merupakan salah satu Kelurahan yang paling tertinggal di Kota Metro bila dibandingkan dengan kelurahan lainnya. Masyarakat yang mendiami kelurahan ini umumnya dalah petani dan buruh, umumnya buruh pabrik yang ada di wilayah kecamatan Metro utara.

Bentuk mata pencaharian dengan menjadi buruh dan bertani tidak dapat dijadikan pemenuhan standar kehidupan masyarakat kota. Artinya, bila dinilai, pada dasarnya pendapatan mereka tidak setara dengan pengeluaran mereka. Terlebih Kota Metro merupakan salah satu kota yang ada di propinsi Lampung, di mana harga komoditas dan kebutuhan masyarakat cenderung lebih tinggi bila dibandingkan dengan harga di desa-desa.

Jamaah yang menjadi subyek pemberdayaan pemberdayaan ini adalah masyarakat miskin yang memang perlu untuk dierdayakan. Umumnya mereka dapat membangun rumah karena mendapatkan fasilitas dana bedah rumah dari pemerintah Kota Metro. Meskipun hidup dalam keterbatasan ekonomi, komitmen mereka untuk membangun dan meningkatkan kesejahteraan cukup tinggi. Semangat mereka untuk bekerja cukup kuat. Hal inilah yang sebenarnya penting dan urgen dalam pemberdayaanmasyarakat. ${ }^{50}$

48 Putman dalam Talja Blokland dan Mike Savage, ed., Networked Urbanism Social Capital in the City (Burlington: Ashgate Publishing Limited, 2008), 2.

49 M. Rezaul Islam, NGOs, Social Capital and Community Empowerment in Bangladesh, 68.

${ }^{50}$ Anyualatha Haridison, “Modal Sosial dalam Pembangunan,” 33. 
Subyek pemberdayaan dalampemberdayaan masyarakat kota umumnya adalah masyarakat miskin, demikian juga dengan pemberdayaan yang dilakukan ini. Namun, demikian, masyarakat miskin yang ada di kelurahan Karangrejo, Kota Metro bukanlah masyarakt miskin urban. Mereka adalah penduduk asli kelurahan karangrejo.

Bila dikategorikan, mereka termasuk kategori miskin relatif. Kemiskinan relatif ditafsirkan dalam kaitannya dengan standar kehidupan masyarakat yang berlaku, mengakui secara eksplisit kesalingtergantungan antara garis kemiskinan dan seluruh distribusi pendapatan. ${ }^{51}$

Subyek pemberdayaan ini tidak dikategorikan sebagai urban poverty, yang biasanya kehidupannya lebih memprihatinkan. Biasanya kemiskinan yang dialami oleh kaum urban cukup menyedihkan. Mereka hidup tanpa akses ke tempat penampungan yang memadai, air bersih, dan sanitasi dasar. Selain itu, Kerimbunan dan degradasi lingkungan membuat kaum miskin kota sangat rentan terhadap penyebaran penyakit. Mereka tinggal di kawasan kumuh. Tanpa kepemilikan lahan atau penguasaan lahan, mereka menghadapi ancaman penggusuran terus-menerus. ${ }^{52}$ Keadaan semacam ini tidak dialami oleh subyek pemberdayaan pemberdayaan ini. Mereka masih hidup laak dannormal, hanya seja kebutuhan dasar dan pendidikan tidak terpenuhi secara maksimal.

Kemiskinan umumnya dipahami sebagai aspek status sosial yang tidak setara, hubungan sosial yang tidak setara, dialami sebagai pengucilan sosial, ketergantungan, dan berkurangnya kapasitas untuk berpartisipasi atau untuk mengembangkan hubungan yang bermakna dengan orang lain dalam masyarakat. ${ }^{53}$ Masyarakat miskin kota biasanya diidentikan dengan masyarakat urban, atau biasa disebut dengan istilah urban poverty.

51 Yusuff Jelili Amuda, "Empowerment of Nigerian Muslim Households through Waqf, Zakat, Sadaqat and Public Funding," International Journal of Trade, Economics and Finance 4, no. 6 (2013): 421, doi:10.7763/IJTEF.2013.V4.329.

52 Allison M dkk., ed., Global Urban Poverty: Setting The Agenda (Washington, D.C: Woodrow Wilson International Center for Scholars, 2007), 1-2.

53 Silver dalam Bala Ram Acharya, "Urban Poverty: A Sociological Study of Shankhamul Squatter," Dhaulagiri Journal of Sociology and Anthropology 4 (2010): 181. 


\section{Pemberdayaan Masyarakat dengan Pengembangbiakkan Kambing}

Peberdayaan masyarakat yang dilaksanakan oleh Pusat Pengabdian Lembaga Penelitian dan Pengabdian kepada Masyarakat (LPPM) IAIN Metro adalah pengembangbiakkan ternak berupa kambing. Modal yang diberikan untuk kegiatan ekonomi subyek datau masyarakat dampingan adalah induk kambing. Pemberian modal awal berupa induk kambing ini diharapkan, paling lambat satu tahun setelah penyerahan kepada pemelihara, kambing tersebut sudah berkembang biak. Dengan demikian akan mempunyai nilai ekonomis dan menjadi penghasilan bagi pemelihara sebagai subyek pemberdayaan.

Pihak LPPM IAIN Metro membuat kriteria subyek pemberdayaan yang paling berhak untuk menjadi Pemelihara pertama. Kriteria tersebut antara lain, kondisi ekonomi subyek pemberdayaan lebih rendah, mempunyai komitmen lebih tinggi dan pertimbangan yang penting adalah subyek pemberdayaan mempunyai anak yang sedang menempuh pendidikan, khususnya pendidikan formal, sekolah atau kuliah.

Sumber dana untuk pembelian induk kambing tersebut secara garis besar ada dua macam, yaitu dana pengabdian Dosen IAIN Metro dan yang kedua berasal dari dana zakat profesi Dosen IAIN Metro. Perbedaan sumber dana pemberdayaan untuk modal pengembangbiakkan kambing ini berimplikasi pada karakteristik pemelihara, model pemeliharaan dan pembagian hasil pengembangbiakkan kambing tersebut. Secara lebih rinci dapat dijelaskan sebagai berikut:

\section{Modal pemberdayaan berasal dari dana pengabdian Dosen}

Model pemberdayaan danpendampingan pengembangbiakkan kambing ini sudah lebih dulu dilaksanakan. Hanya saja, program pengembangbiakkan kambing ini pada tahun-tahun awal tidak berjalan efektif, karena minimnya pengawasan dan dampingan di pihak LPPM IAIN Metro. Setelah beberapa tahun berjalan, pihak LPPM IAIN metro melakukan pendataan kembali terhadap aset hewan pemberdayaan sebagai program pengabdian. Kambingkambing yang sudah ada diserahkan kepada subyek pemberdayaan untuk dipelihara dan dikembang biakkan.

Secara rinci, data dan jumlah kambing yang modalnya berasal dari dana pengabdian dosen yang dipelihara oleh subyek pemberdayaan adalah sebagai berikut: 
Perkembangan Kambing Peliharaan Subyek Pemberdayaan Di Desa Binaan Karangrejo Metro Utara Tahun 2014-2017 Yang Modalnya Berasal Dari Dana Pengabdian Dosen

\begin{tabular}{|c|c|c|c|c|c|c|c|}
\hline \multirow[t]{2}{*}{ No } & \multirow[t]{2}{*}{ Pengelola } & \multirow{2}{*}{$\begin{array}{l}\text { Modal } \\
\text { awal }\end{array}$} & \multicolumn{5}{|c|}{ Perkembangan/Tahun } \\
\hline & & & $\mathbf{I}$ & II & III & IV & $\mathbf{V}$ \\
\hline 1. & P-I (Y) & 2 Ekor & 4 Ekor & 6 Ekor & 11 Ekor & 14 Ekor & 6 Ekor \\
\hline 2. & P-IA (S) & & & & 2 Ekor & 6 Ekor & 7 Ekor \\
\hline 3. & P-IB (D) & & & & 3 Ekor & - & - \\
\hline 4. & P-IC (U) & & & & 1 Ekor & 3 Ekor & 5 Ekor \\
\hline 5. & P-II (K) & 2 Ekor & 4 Ekor & 6 Ekor & 8 Ekor & 8 Ekor & 10 Ekor \\
\hline 6. & P-II A (B) & & & & & 5 Ekor & 8 Ekor \\
\hline 7. & P-IIB (L) & & & & & 3 Ekor & 5 Ekor \\
\hline 8. & PIII (Ti) & & & & 1 Ekor & 2 Ekor & 5 Ekor \\
\hline 9. & P-IV (Wa) & & & & 1 Ekor & 1 Ekor & 1 Ekor \\
\hline 10. & $\mathrm{P}-\mathrm{V}(\mathrm{Tu})$ & & & & 1 Ekor & - & - \\
\hline 11. & P-VI (W) & & & & & 1 Ekor & 1 Ekor \\
\hline JUI & $\mathrm{AH}$ & 4 & 8 & 12 & 28 & 43 & 58 \\
\hline
\end{tabular}

\section{Keterangan:}

P-I $-\mathrm{P}$-VI $\quad=$ Pemelihara peratama samapai pemelihara keempat yang menerima modal awal dari pihak LPPM IAIN Metro

P-IA, B, dan = Pemelihara lanjutan yang modal awalanya berupa kambing betina dari pemelihara pertama, atau induk yang digulirkan dari pihak pertama.

$\mathrm{P}$-II A dan $\mathrm{B} \quad=$ Pemelihara lanjutan yang modal awalanya berupa kambing betina dari pemelihara kedua, atau induk yang digulirkan dari pihak kedua.

Ada beberapa karakteristik model pemeliharaan kambing yang modalnya berasal dari dana pengabdian yang secara rinci dapat dijelaskan sebagi berikut: 


\section{a. Tidak menjadi hak milik}

Pada model pemberdayaanyang modal awalnya berasal dari dana pengabdian Dosen, induk kambing atau modal awal yang diserahkan kepada pemelihara tidak menjadi hak milik pemelihara. Induk kambing tersebut bisa berpindah tangan sewaktu-waktu bila pemelihara sudah mendapatkan keuntungan berupa anak kambing dan dirasa cukup untuk dikembang biakkan. Begitu juga disaat penerima modal awal merasa tidak mampu untuk memelihara induk kambing maka bisa dipindahkan kepada subyek pemberdayaan lain yang siap memeliharanya.

\section{b. Komitmen pemelihara tinggi}

Para pemelihara induk kambing yang menjadi subyek pemberdayaan dengan modal dari dana pengabdian umumnya mempunyai komitmenyang tinggi untuk mememlihara danmengembang-biakkannya. Hal ini karena mereka hanya berhak untuk memiliki hasil atau anak dari induk tersebut. Mereka tidak berhak memiliki atau menjual induknya, karena induk tersebut adalah modal awal yang harus digulirkan.

\section{c. Produktif}

Adanya komitmen dan semangat yang tinggi dari subyek pemberdayaan pemelihara induk kambing berpengaruh pada perkembangan kambing yang dipelihara. Misalnya pada waktu induk kambing dikawinkan, maka pemelihara dengan kesadarn sendiri mengawinkannya, sehingga segera hamil dan beranak-pinak.

\section{d. Bergulir}

Induk kambing yang dipelihara oleh seorang subyek pemberdayaan akan digulirkan kepada subyek pemberdayaan lain yang juga membutuhkan. Pemindahan ini dilakukan setelah pemelihara pertama mendapatkan keuntungan berupa anak kambing setelah memelihara setidaknya satu tahun.

\section{e. Ada bagi hasil}

Model pemberdayaan dengan modal berasal dari dana pengabdian dilakukan dengan sistem bagi hasil. Perhitungan bagi hasilnya yaitu, anak pertama dari induk kambing yang dipelihara menjadi hak milik subyek pemberdayaan pemelihara. Sementara untuk anak-anak pada tahap berikutnya akan dibagi menjadi dua atau bagihasil dengan nisbah 50:50. Hanya saja, pemelihara berhak memilih anak kambing yang mana yang akan dia miliki 
sebagai hasil. Misalnya pada tahun kedua induk kambing melahirkan dua ekor anak, maka satu anak menjadi bagian pemelihara dan satunya menjadi hak pihak LPPM IAIN Metro. Anakan kambing yang menjadi bagian LPPM ini bila sudah besar dan dipasahkan dari induknya biasanya akan diserahkan kepada pemelihara lain yang menjadi subyek pemberdayaan.

\section{Modal pemberdayaan berasala dari zakat profesi Dosen}

Pemberdayaan zakat profesi scara produktif melalui pengembangbiakkan kambing dimulai pada awal tahun 2017. Pada saat itu dana zakat hanya cukup untuk membeli dua induk kambing yang diserahkan kepada dua mustahiq yang juga menjadi subyek pemberdayaan. Kemudian pada tahun 2017 ada tambahan dana zakat profesi yang dibelikan dua induk kambing lagi dan diserahkan kepada mustahiq lain yang juga menjadi subyek pemberdayaan.

Pemberdayaan dana zakat untuk mustahiq harus disesuaikan dengan potensi pengembangan yang bisa dilakukan oleh mustahiq agar pemberdayaan berjalan optimal. ${ }^{54}$ Bila pemberdayaan bisa berhasil, maka akan dapat membantu perekonomian mustahiq ${ }^{55}$ sebagai subyek pemberdayaan. Dana zakat diharapkan dapat mengentaskan kemiskinan, sehingga mereka mempunyai kemandirian ekonomi. ${ }^{56}$ Lebih dari itu, zakat diharapkan menjadi sarana untuk kegiatan produktif dan peningkatan pendidikan, khususnya bagi mustahiq. ${ }^{57}$

54 Tika Widiastuti, Raditya Sukmana, dan Sri Herianingrum, "The Role of Economic Empowerment for The Poor in a Zakat Institution" (Proceedings of Sydney International Business Research Conference 2015, University of Western Sydney Campbelltown, Australia, 2015), 673.

${ }^{55}$ Keumala Hayati dan Indra Caniago, "Model Of Poor Society Empowerment Through Optimizing The Potential Of Zakat," Journal of Indonesian Economy and Business 27, no. 2 (2012): 178.

56 Yusuff Jelili Amuda, "Empowerment of Nigerian Muslim Households through Waqf, Zakat, Sadaqat and Public Funding," 419.

57 Hamzah Hamzah, "Empowerment of Mustahiq Zakat Model Towards Business Independency," International Journal of Nusantara Islam 5, no. 1 (19 Maret 2017): 85, doi:10.15575/ijni.v5i1.1546. 
Berkaitan dengan pemberdayaan dana zakat produktif melalui pengembangbiakkan kambing ini, ada kriteria tertentu untuk mustahiq yang berhak menerima dana zakat produktif sebagai mdal untuk membeli induk kambing. Kriteria tersebut antara lain, mustahiq tersebut dalam kategori miskin, mempunyai komitmen tinggi, dan serta mempunyai anak yang sedang menempuh pendidikan, khususnya pendidikan formal, sekolah atau kuliah.

Kambing-kambing yang diserahkan kepada mustahiq untuk dipelihara berupa indukan. Ada beberapa karakteristik model pemeliharaan kambing yang modalnya berasal dari dana zakat produktif dosn yang secara rinci dapat dijelaskan sebagi berikut:

\section{a. Menjadi hak milik}

Berbeda dengan pemiliharan yang pertama, pemeliharaan dan pengebangbiakkan kambing yang dananya berasal dari zakat profesi dosen ini induk kambing yang diserahkan kepada mustahiq zakat menjadi hak miliknya secara penuh. Mustahiq mempuyai kuasa penuh atas induk kambing yang diterima dan dipeliharanya. Bahkan ia berhak untuk menjualnya kapan saja bila diperlukan. Hanya saja ditekankan agar kambing tersebut dikembang biakkan, sehingga tujuan pemberdayaan ekonomi melalui zakat produktif dapat tercapai. Berapapun anak yang dilahirkan atau keuntungan yang berasal dari pemeliharaan kambing tersebut menjadi hak penuh meustahik pemilhara tanpa ada bagi hasil dengan siapa pun.

\section{b. Perkembangan lebih lamban}

Ini merupakan kelemahan dari penyerahan secara penuh induk kambing kepada mustahiq sebagai subyek pemberdayaan. Karena meras bahwa induk kambing tersbut menjadi hak milik penuh dan tidak dipindahtngankan, maka komitmen dan semangat mustahiq yang menjadi pemilik tersebut tidak cukup tinggi. Akibatnya perkembangan kambing lamban. Bahkan ada mustahiq yang menjual induk kambing yang dipelihara beberapa bulan namun belum hamil. 


\section{c. Tidak digulirkan}

Dana zakat profesi yang kemudian diserahkan dan dibelikan induk kambing menjadi hak milik penuh mustahiq. Karena ia merupakan harta zakat memang menjadi hak mustahiq. Induk kambing tersebut tidak digulirkan atau dipindhtangankan. Ia berhak untuk memeliharanya atau pun menjualnya. Meskipun pada dasarnya pemberian zakat sebagi modal tersebut tujuannya adalah untuk dikembangkan agar lebih produktif dan dapat membantu ekonomi mustahiq.

\section{E. Penutup}

Pemberdayaan jamaah yasinan dan pengajian di keluarahan Karangrejo, kecamatan Metro Utara, Kota Metro berjalan efektif. Aset pemberdayaan yang dikelola oleh jamaah yasinan dan pengajian sebagai subyek pemberdayaan bisa berkembang. Hewan ternak berupa kambing berkembang biak dan dapat bergulir dari anggota jamaah ke anggota yang lain. Namun demikian, tidak semua subyek pemberdayaan dapat menjalankan perannya secara maksimal. Beberapa subyek permberdayaan yang gagal mengembangbiakkan kambing.

Berdasarkan evaluasi dan pengamatan lapangan, kajian ini menyimpulkan bahwa keberhasilan program pemberdayaan melalui pengembangbiakkan kambing tidak hanya ditentukan jumlah modal yang diberikan, akan tetapi oleh spirit dan komitmen subyek pemberdayaan. Selain itu, faktor lain yang mempengaruhi keberhasilan pemberdayaan ini adalah manajemen pengelolaan modal dan aset pemberdayaan.

Ketika hewan piaraan yang berupa kambing betina tidak menjadi hak milik, maka semangat subyek pemberdayaan untuk memelihara hewan tersebut lebih tinggi. Selain itu, mereka lebih menjaga komitmen untuk memelihara kambing-kambing tersebut. Model semacam ini lebih efektif dan mencapai tujuan pemberdayaan. Sementara model pemberdayaan yang modalnya berasal dari dana zakat profesi berupa kambing yang diserahkan kepada mustahiq untuk menjadi hak milik dan tidak bergulir, umumnya komitmen dan kesriusan penerima kurang maksimal. Akibatnya, tujuan pemberdayaan tidak tercapai secara maksimal[.] 


\section{REFERENSI}

Alan Kay. "Social Capital, the Social Economy and Community Development." Community Development Journal 41, no. 2 (1 April 2006): 160-73. doi:10.1093/cdj/bsi045.

Alina Mihaela Dima, Simona Vasilache, Valentina Ghinea, dan Simona Agoston. "A Model Of Academic Social Responsibility," t.t., 21.

Allison M, Garland, Mejgan Massoumi, dan Blair A. Ruble, ed. Global Urban Poverty: Setting The Agenda. Washington, D.C: Woodrow Wilson International Center for Scholars, 2007.

Andi Sopandi. "Strategi Pemberdayaan Masyarakat: Studi Kasus Strategi Dan Kebijakan Pemberdayaan Masyarakat Di Kabupaten Bekasi." Jurnal Kybernan 1, no. 1 (2010): 17.

Andriyani, A.A.I, Martono, E, dan Muhamad. "Pemberdayaan masyarakat melalui pengembangan desa wisata dan implikasinya terhadap ketahanan sosial budaya wilayah (studi di Desa Wisata Penglipuran Bali)." Jurnal Ketahanan Nasional 23, no. 1 (2015).

Anjali Kaur. "Women's Economic Empowerment: Meeting the Needs of Impoverished Women." Workshop Report, 2005.

Anonim. Achieving Community Empowerment, t.t.

Anu Kasmel, dan Pernille Tanggaard Andersen. "Measurement of Community Empowerment in Three Community Programs in Rapla (Estonia)." International Journal of Environmental Research and Public Health 8, no. 3 (11 Maret 2011): 799-817. doi:10.3390/ijerph8030799.

Anyualatha Haridison. "Modal Sosial dalam Pembangunan." JISPAR, FISIP Universitas Palangka Raya 4 (2013).

Bala Ram Acharya. "Urban Poverty: A Sociological Study of Shankhamul Squatter." Dhaulagiri Journal of Sociology and Anthropology 4 (2010).

Bambang Sigit Subiyanto. "Strategi Pemberdayaan Masyarakat," 2013, 4. 
Burhanudin AY. "Perencanaan Program Pemberdayaan Menuju Perubahan Dalam Masyarakat." Paradigma 5, no. 1 (2008).

Caroline Heller. "Community Empowerment And Capacity Building," 2014.

Chripa Schneller, dan Erich Thoni, ed. Knowledge Societies: Universities and Their Social Responsibilities. Singapore: Asia-Europe Foundation, 2011.

Dahlan Tampubolon. "Strategi Pemberdayaan Masyarakat Pesisir Di Kabupaten Kepulauan Meranti." SOROT 9, no. 1 (20 Oktober 2014): 153. doi:10.31258/sorot.8.2.2358.

Dana Rotman, dan PhiliP Fei Wu. Sense of Community in Virtual Environments. New York: ME Sharpe, 2014.

David L Adamson, Richard Bromiley, dan Joseph Rowntree Foundation. Community Empowerment in Practice: Lessons from Communities First. York: Joseph Rowntree Foundation, 2008.

Dewi Maryam. "Perencanaan Partisipatif Dalam Pemberdayaan Masyarakat (Studi Kasus Pelaksanaan Musyawarah Perencanaan Pembangunan (Musrenbang) di Desa Kebumen Kecamatan Sumberjo." Jurnal Ilmu dakwah Dan Pengembangan Komunitas X, no. 1 (2015): 21.

Flores G Mayaut. “Identifikasi Masalah Dan Upaya Pemberdayaan Nelayan: Telaah Pada Nelayan di RW 01 Kelurahan Kamal Muara, Kecamatan Penjaringan, Jakarta Utara." INSANI, no. 13 (2012): 7.

H Elizabeth Peters, Nan Marie Astone, Fenohasina Maret, dan Caroline Heller. Women's Economic Empowerment: A Review of Evidence on Enablers and Barriers. Canada: Hewlett Foundation, 2016. 
Hamzah Hamzah. "Empowerment of Mustahiq Zakat Model Towards Business Independency." International Journal of Nusantara Islam 5, no. 1 (19 Maret 2017): 85. doi:10.15575/ijni.v5i1.1546.

Haris, Andi. "Memahami Pendekatan Pemberdayaan Masyarakat Melalui Pemanfaatan Media." JUPITER XIII, no. 2 (2014): 13.

Hedayat Allah Nikkhah. "Participation as a Medium of Empowerment in Community Development." European Journal of Social Sciences 11, no. 1 (2009): 8.

Hilman, Y.A, dan Nimasari, E.P. “Model program pemberdayaan masyarakat desa berbasis komunitas." ARISTA: Sosial Politik Humaniora 6, no. 1 (2017).

Jaclyn Redekop. "Evaluating Community Development Programs: Who speaks? Who listens? Who cares?" Tesis, University of Manitoba, 2013.

Keumala Hayati, dan Indra Caniago. "Model Of Poor Society Empowerment Through Optimizing The Potential Of Zakat." Journal of Indonesian Economy and Business 27, no. 2 (2012): 18.

Kuswandoro, W.E. Strategi pemberdayaan masyarakat desa berbasis partisipasi: pendekatan good village governance untuk implementasi UU Nomor 6 Tahun 2014, 2016. http://www.researchgate.net/publication/311101048.

M. Noor. "Pemberdayaan masyarakat." Jurnal Ilmiah CIVIS 1, no. 2 (2011). 
M. Rezaul Islam. NGOs, Social Capital and Community Empowerment in Bangladesh. Singapore: Springer Singapore, 2016. doi:10.1007/978-981-10-1747-6.

Martua Hasiholan Bancin. “Peningkatan Partisipasi Masyarakat Dalam Program Nasional Pemberdayaan Masyarakat (Pnpm) Mandiri Perdesaan (Studi Kasus: Bandung Barat)." Jurnal Perencanaan Wilayah dan Kota 22, no. 3 (2011): 16.

McMillan, D.W, dan Chavis, D.M. "Sense of community: A definition and theory." American Journal of Community Psychology 14, no. 1 (1986).

Munawar Noor. "Pemberdayaan Masyarakat." Jurnal Ilmiah CIVIS 1, no. 2 (2011): 13.

Peter Dreier. "Community Empowerment Strategies: The Limits and Potential of Community Organizing in Urban Neighborhoods." Cityscape: A Journal of Policy Development and Research 2, no. 2 (1996): 39.

R Seminur Topal. "CSR in Universities Around the World." SRRNet, 2009, 23.

Radiah Othman, dan Roslan Othman. "Higher Education Institutions And Social Performance: Evidence from Public And Private Universities." International Journal of Business and Society 15, no. 1 (2014).

Ratna Sari Dewi. “Evaluasi Program Pemberdayaan Masyarakat Melalui Pendidikan Kewirausahaan Masyarakat (Pkm) Program Nasional Pemberdayaan Masyarakat (Pnpm) Di Desa Balonggandu Kecamatan Jatisari Kabupaten Karawang" 1, no. 2 (t.t.). 
Ravik Karsidi. "Paradigma Baru Penyuluhan Pembangunan dalam Pemberdayaan Masyarakat." Mediator 2, no. 1 (2001): 11.

Robert Adams. Social Work and Empowerment. 3rd ed. Practical Social Work. Basingstoke: Palgrave Macmillan, 2003.

Rokhani. "Penguatan Modal Sosial Dalam Penanganan Produk Olahan Kopi Pada Komunitas Petani Kopi Di Kabupaten Jember." J-SEP 6, no. 1 (2012).

Rusydi Syahra. "Modal Sosial: Konsep dan Aplikasi." Jurnal Masyarakat dan Budaya 5, no. 1 (2003): 22.

Shannon Mason, Judiann McNulty, dan Judi Aubel. "Participation for Empowerment," 2001, 101.

Steve et. Building Community Capacity Resources for Community Learning $\mathcal{E}$ Development Practice. Scottish Government, 2007.

Subhan Arif. "Peranan Dosen IAIN Raden Intan Lapung dalam Pemberdayaan Melalui Pengabdian Masyarakat di Kec. Sukarame Bandar Lampung." Jurnal Ilmu dakwah Dan Pengembangan Komunitas 9, no. 2 (2014): 23.

Sukaina A Alzyoud, dan Kamal Bani-Hani. "Social Responsibility In Higher Education Institutions: Application Case from the Middle East." European Scientific Journal 11, no. 8 (2015): 9.

Takashi Miyazaki. "Community Development as Community Empowerment." Study of Community Education, no. 33 (2015): 14. Talja Blokland, dan Mike Savage, ed. Networked Urbanism Social Capital in the City. Burlington: Ashgate Publishing Limited, 2008.

Tika Widiastuti, Raditya Sukmana, dan Sri Herianingrum. "The Role of Economic Empowerment for The Poor in a Zakat Institution." Proceedings of Sydney International Business Research Conference 2015, University of Western Sydney Campbelltown, Australia, 2015. 
Trisni Utami. “Pemberdayaan Komunitas Sektor Informal Pedagang Kaki Lima (Pkl), Suatu Alternatif Penanggulangan Kemiskinan" 25, no. 2 (2010): 10.

Yunus Winoto. "Pemberdayaan Masyarakat (Community Empowerment) Melalui Penyelenggaraan Taman Bacaan Masyarakat (TBM): Studi kasus mengenai penyelenggaraan taman bacaan masyarakat (TBM) di wilayah Kabupaten Bandung." Prosiding Seminar Nasional Pendidikan FKIP UNTIRTA, Serang, 2017.

Yusuff Jelili Amuda. "Empowerment of Nigerian Muslim Households through Waqf, Zakat, Sadaqat and Public Funding." International Journal of Trade, Economics and Finance 4, no. 6 (2013): 419-24. doi:10.7763/IJTEF.2013.V4.329. 
\begin{tabular}{l|l} 
Gerakan Tablighi di Kalimantan Timur ... & 295
\end{tabular} 
296 | AKADEMIKA, Vol. 22, No. 02 Juli - Desember 2017 